\title{
Efficacy of sorafenib after liver transplantation in patients with primary hepatic carcinoma exceeding the Milan criteria: a preliminary study [Expression of concern] [Erratum]
}

\author{
Huang L, Li G, Zhu J, Li Z, Li T, Leng X. Onco Targets \\ Ther. 2020;13:3289.
}

Due to a processing error the link for the British Medical Journal Open (BMJ Open) article described was missing.
The link for the BMJ Open article has been provided here: http://dx.doi.org/10.1136/bmjopen-2018-024473.

\section{Publish your work in this journal}

OncoTargets and Therapy is an international, peer-reviewed, open access journal focusing on the pathological basis of all cancers, potential targets for therapy and treatment protocols employed to improve the management of cancer patients. The journal also focuses on the impact of management programs and new therapeutic agents and protocols on patient perspectives such as quality of life, adherence and satisfaction. The manuscript management system is completely online and includes a very quick and fair peer-review system, which is all easy to use. Visit http://www.dovepress.com/ testimonials.php to read real quotes from published authors. 